\title{
The FHA AND THE GSEs AS CountercyClical ToOls IN The Mortgage Markets
}

\author{
Wayne Passmore and Shane M. Sherlund
}

\section{OVERVIEW}

- A common objective of federal government mortgage-market programs is to limit the financial shocks felt by households during and after severe housing market downturns.

- Using county-level data, this article examines how pre-crisis participation in the mortgage programs of the Federal Housing Administration (FHA), the U.S. Department of Veterans Affairs (VA), and the government-sponsored enterprises (GSEs) Fannie Mae and Freddie Mac influenced the real economy during and after the Great Recession.

- The authors find a strong correlation between a greater reliance on FHANA or GSE lending before the financial crisis and better economic outcomes during and after the 2007-09 financial crisis.

- Moreover, the analysis shows that the FHANA lending was a more effective countercyclical tool during and after the 2007-09 financial crisis than GSE lending. he federal government funds and charters a wide variety
of mortgage-market programs that differ greatly in size, scope, and structure. One unifying objective of these programs is to limit damage to households during and after severe housing market downturns. The 2007-09 financial crisis and the Great Recession provide an opportunity to compare empirically the effects of government mortgage programs. This raises a critical question: What were the most effective countercyclical tools used in response to the recession?

In this article, we compare the efficacy of two avenues through which the government participates in the mortgage market: (1) mortgages insured by the Federal Housing Administration (FHA) or the Veterans Affairs (VA) loan guarantee programs and securitized by the Government National Mortgage Association (Ginnie Mae); and (2) mortgages securitized by the Federal National Mortgage Association (Fannie Mae) or the Federal Home Loan Mortgage Corporation (Freddie Mac), institutions often referred to as government-sponsored enterprises (GSEs). We find that greater pre-crisis participation in FHA/VA or GSE lending is strongly correlated with better economic outcomes. Furthermore, we find that FHA/VA lending was more effective than GSE lending during and after the Great Recession.

Wayne Passmore is a senior advisor and Shane M. Sherlund an assistant director in the Division of Research and Statistics at the Board of Governors of the Federal Reserve System. Email: wayne.passmore@frb.gov; shane.m.sherlund@frb.gov.

The views expressed in this article are those of the authors, do not necessarily reflect the position of the Federal Reserve Bank of New York and should not be interpreted as representing the views of the Federal Open Market Committee, its principals, the Board of Governors of the Federal Reserve System, or the Federal Reserve System. To view the authors' disclosure statements, visit https://www.newyorkfed.org/research/epr/2018/epr_2018_fha-and-gses_passmore. 
Chart 1

Pre-Crisis FHANA Share and GSE Share Distributions

FHA/VA share

GSE share

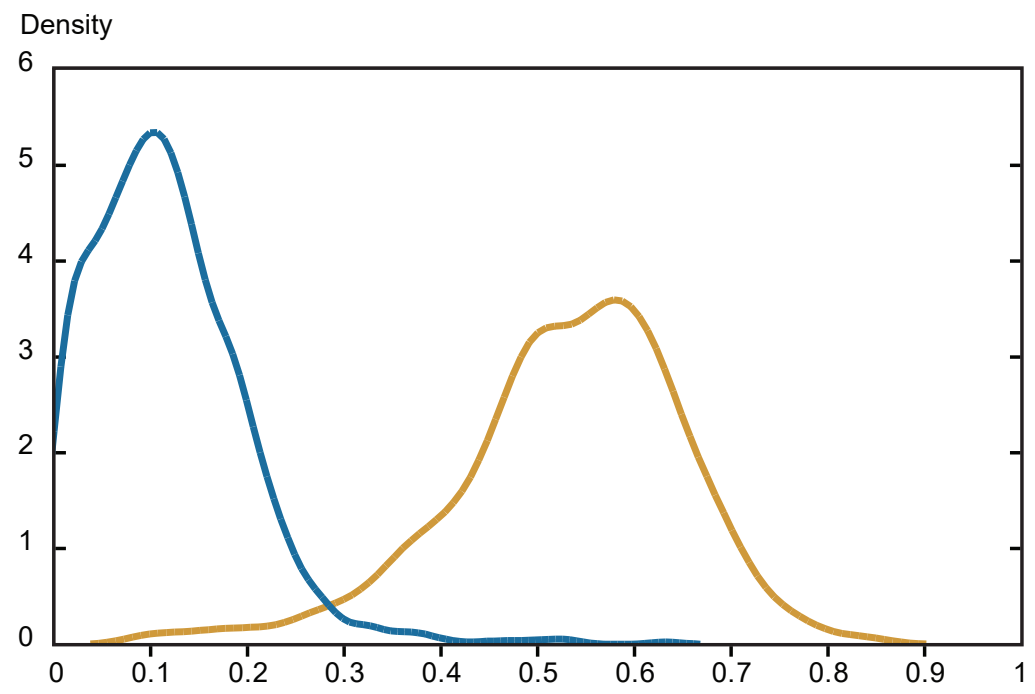

Source: Authors' calculations, based on BlackKnight McDash, CoreLogic, and Home Mortgage Disclosure Act data.

Note: Chart shows kernel density estimates of the FHA/VA and GSE market share distributions of purchase mortgage originations across counties during the period from 2004 through the first half of 2007.

We characterize the mortgage market structure for each county in the United States in terms of the proportion of mortgages originated in the county that are insured by the FHA or the VA and then securitized through Ginnie Mae (the FHA/VA share), and the proportion of mortgages securitized by Fannie Mae or Freddie Mac (the GSE share), during the period from 2004 through the first half of 2007. The empirical distributions in Chart 1 illustrate the significant variation among counties in government program use before the financial crisis. Pre-crisis FHA/VA shares ranged from close to zero to more than 60 percent. GSE shares ranged from about 10 percent to over 85 percent. The median county had an 11 percent pre-crisis FHA/VA share and a 54 percent GSE share.

Exhibits 2A and 2B show that FHA/VA and GSE shares displayed significant geographic variation during the period from 2004 through the first half of 2007. FHA/VA shares were highest in the Midwest and lowest along the coasts. In general, GSE shares were higher than FHA/VA shares and were highest in the Midwest and Appalachia and lowest in parts of Arizona, California, Florida, and Nevada, and a few large metropolitan areas such as Washington D.C.

In the remainder of this article, we examine how pre-crisis participation in FHA/VA and GSE programs influenced the real economy across counties during and after the Great Recession. However, participation in government programs may not be independent of conditions that create better economic performance. Thus, we control for the ability of each county to select its government mortgage program use conditional on the county's economic fundamentals-such as average income, house prices, and 
Exнівіт 2A

FHANA Shares during the 2004-07 Period

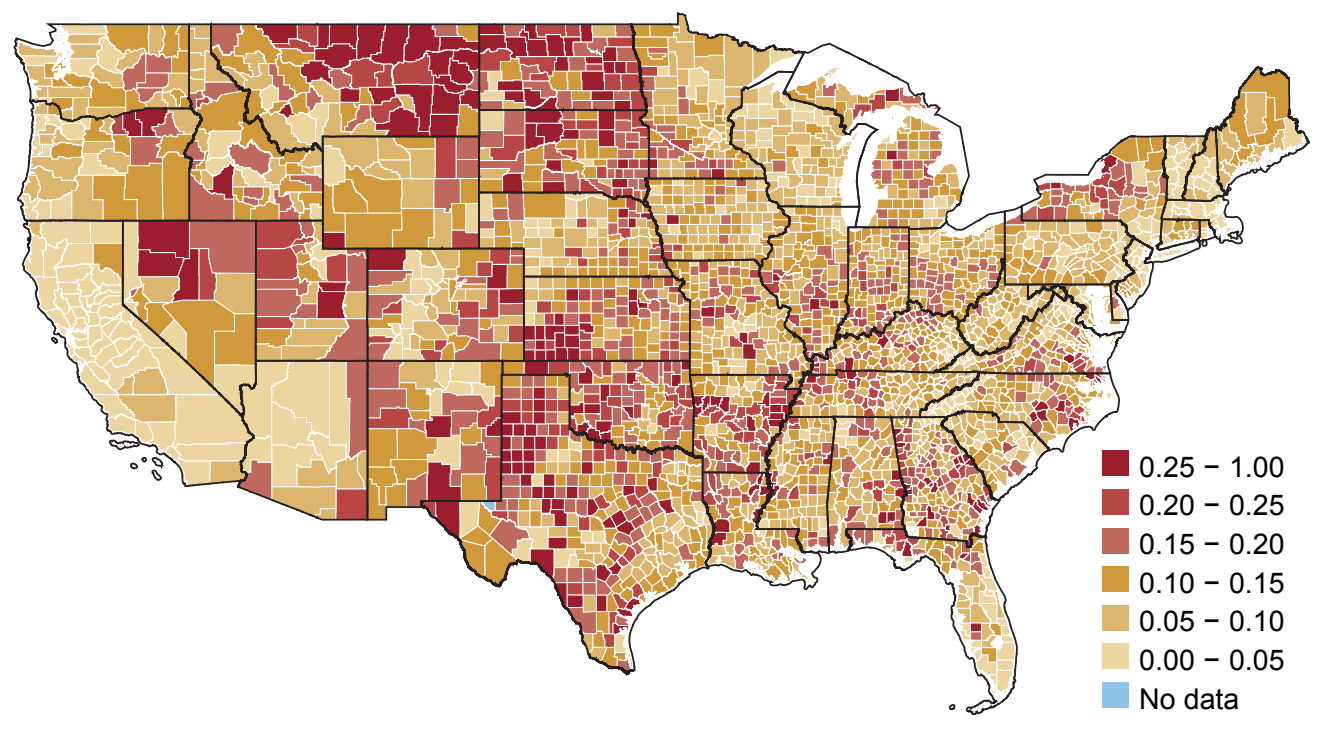

Source: Authors' calculations, based on BlackKnight McDash, CoreLogic, and Home Mortgage Disclosure Act data.

Note: Chart shows FHA/VA market shares of purchase mortgage originations during the period from 2004 through the first half of 2007 , by county.

unemployment rates - and other characteristics — such as age, education, race, and ethnicity. In particular, we include county-level house prices before and during the housing boom. Based on the entire set of economic fundamentals, we estimate the probability, or propensity score, that each county would select its observed FHA/VA or GSE share. Conditional on our estimated propensity scores, counties experienced similar house price appreciation and unemployment rates before the financial crisis. After the crisis began, however, house prices and unemployment rates deviate among counties with high or low levels of government involvement, yet similar propensity scores (Passmore and Sherlund 2017).

By controlling for the propensity of a county to select FHA/VA and GSE shares, we can directly estimate the effect of government financing alternatives on economic activity in a county (Passmore and Sherlund 2016). We draw on the wide variation across counties in government mortgage program participation and in economic outcomes during and after the financial crisis. We find that counties with higher pre-crisis FHA/VA or GSE shares had smaller increases in mortgage delinquency rates; smaller declines in mortgage purchase originations, home sales, home prices, and new automobile purchases; and smaller increases in unemployment rates compared with counties with lower pre-crisis FHA/VA or GSE shares. These results hold both in 2009, right after the peak of the financial crisis, and in 2014, six years after the crisis. ${ }^{1}$ Moreover, we find that FHA/VA lending was more effective than GSE lending during and after the Great Recession. 


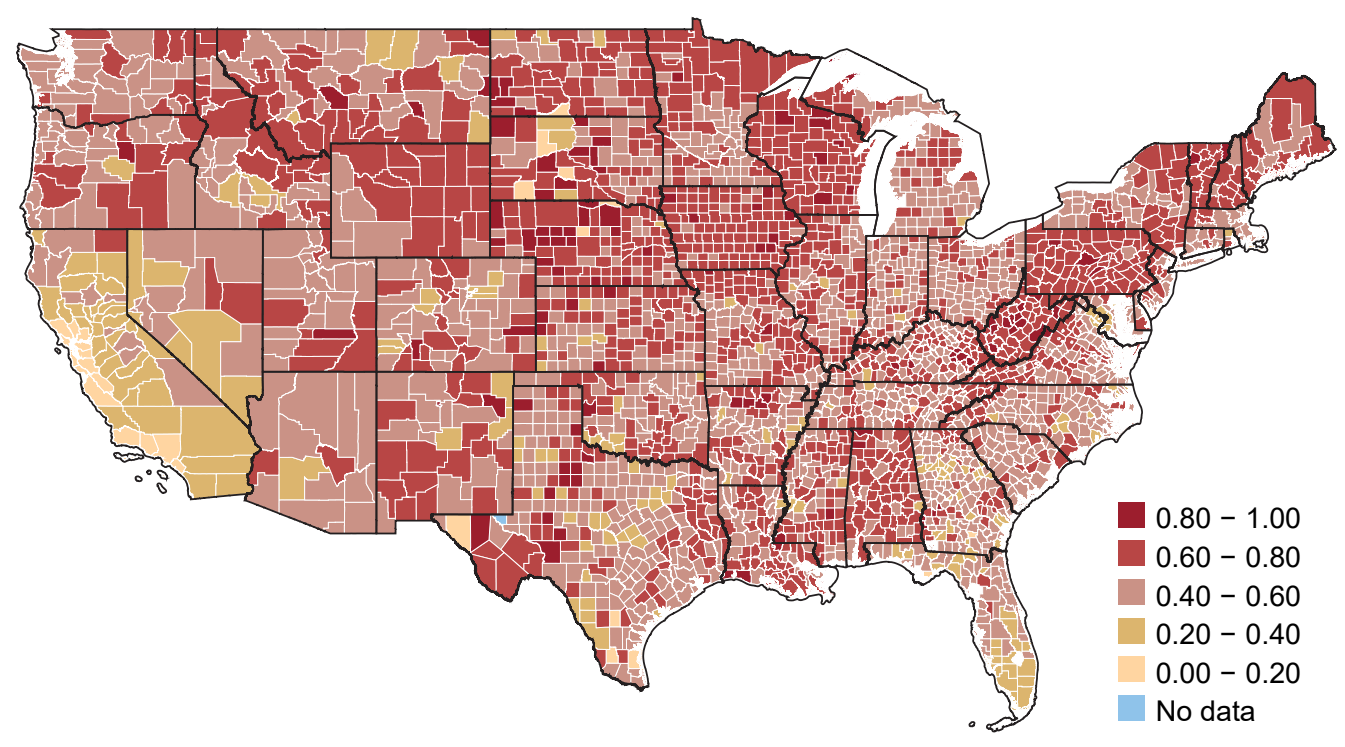

Source: Authors' calculations, based on BlackKnight McDash, CoreLogic, and Home Mortgage Disclosure Act data.

Note: Chart shows GSE market shares of purchase mortgage originations during the period from 2004 through the first half of 2007 , by county.

\section{Differences between the FHA and the GSEs}

The FHA is a government agency that extends credit to marginal mortgage borrowers who would usually not qualify for a private sector 30-year fixed-rate mortgage. Many of these borrowers are first-time homebuyers. The FHA provides mortgage insurance to the lender that covers losses if these borrowers default. The borrower makes a small down payment and pays the monthly mortgage insurance premiums, which are often higher than private sector alternatives. FHA premiums have ranged from 50 basis points to 135 basis points (Chart 2, page 34). Borrowers also make an upfront payment to acquire FHA mortgage insurance. ${ }^{2}$

A mortgage issuer can bundle FHA-insured mortgages and create a pool of mortgagebacked securities (MBS). That issuer may or may not have originated the mortgages. In return for a fee, the issuer can buy a guarantee from Ginnie Mae for the MBS. Ginnie Mae will guarantee timely payment of principal and interest, which means the cash flows due to investors will not be interrupted if borrowers default.

If a borrower with a mortgage in the pool defaults, then the mortgage issuer is responsible for making up the shortfall in principle and interest payments. Because these mortgages are insured, the FHA will eventually compensate the mortgage issuer for the default. However, if the issuer itself defaults, Ginnie Mae steps in to cover interest and principle payments to the MBS investor. Thus, Ginnie Mae MBS have a 
full-faith-and-credit guarantee from the U.S. government. Ginnie Mae cannot default because it is able to draw funds to cover its losses from the U.S. Treasury in the highly unlikely event it becomes insolvent.

In contrast, Fannie Mae and Freddie Mac can default on their debt. Furthermore, Fannie Mae and Freddie Mac MBS do not have a full-faith-and-credit guarantee from the U.S. government. Mortgage originators either sell mortgages to the GSEs or swap mortgages for GSE MBS. Fannie Mae and Freddie Mac guarantee timely payment of principle or interest to holders of GSE MBS. If a borrower defaults, the GSE moves the mortgage from the mortgage pool to the GSE's own balance sheet. However, if many mortgages were to default at the same time, a GSE could itself become insolvent. The GSE's regulator, the Federal Housing Finance Agency (FHFA), may then place the GSE into conservatorship or receivership. As stated on the FHFA website (FHFA 2017):

On September 6, 2008, FHFA used its authorities to place Fannie Mae and Freddie Mac into conservatorship. This was in response to a substantial deterioration in the housing markets that severely damaged Fannie Mae and Freddie Mac's financial condition and left them unable to fulfill their mission without government intervention.

A key component of the conservatorships is the commitment of the U.S. Department of the Treasury to provide financial support to Fannie Mae and Freddie Mac to enable them to continue to provide liquidity and stability to the mortgage market.

The FHA is different from Fannie Mae and Freddie Mac in three important ways. First, the FHA is directly part of the government. Second, the FHA is more targeted toward mortgage borrowers with lower credit scores and smaller down payments. Third, FHA mortgages are securitized by an entity with the full faith and credit of the government. In contrast, Fannie Mae and Freddie Mac are owned by private shareholders, are tasked with making mortgages widely available through secondary market activities, and can only receive government assistance through conservatorship. The result is that the FHA is more willing to extend credit to marginal borrowers after housing market downturns by providing them mortgage insurance, particularly borrowers with mortgages that have high loan-to-value ratios.

Such differences may change the government's response to severe economic downturns. The FHA may willingly extend credit to borrowers affected by a recession and its mortgages have a ready securitization outlet unaffected by the credit quality of the mortgages or the state of the mortgage market. In contrast, the GSEs may reluctantly extend credit to marginal borrowers after household credit quality has been damaged by a recession and their own solvency status might impede their ability to securitize mortgages. Furthermore, the private sector might impose overlays on the GSEs' underwriting and credit pricing. The 2007-09 financial crisis and the ensuing recession provide a way to empirically test the effects on economic recovery of these two forms of government involvement. 


\section{EMPIRICAL APPROACH}

Our identification strategy distinguishes between the FHA/VA and the GSEs during the economic recovery, relying on the variation in government involvement in mortgage markets across counties prior to the 2007-09 financial crisis. Counties with significant FHA/VA involvement are subject primarily to underwriting and credit risk pricing standards available to marginal mortgage borrowers. In contrast, counties with little pre-crisis FHA/VA involvement may have large pre-crisis involvement from Fannie Mae and Freddie Mac (or private lenders), and might be subject primarily to underwriting and credit risk pricing overlays set by local banks, thrifts, mortgage banks, and private-sector mortgage securitization conduits. These underwriting and credit risk pricing overlays may or may not be set at the national level and are likely to be more varied and responsive to current market conditions.

Consider three counties with different mortgage financing structures before the financial crisis: County A relies primarily on private financing, County B relies on GSE financing, and County $\mathrm{C}$ relies on FHA/VA financing. All three forms of financing are available in each county, but county characteristics and economic fundamentals drive each county to choose different combinations of mortgage finance.

Once the financial crisis started, private sources of financing dried up. This lack of funding might have forced County A to transition from private financing toward GSE and FHA/VA financing. Given that many forms of pre-crisis private financing had very loose underwriting standards, County A viewed both FHA/VA and GSE underwriting standards as relatively strict. This tightening of credit availability can be viewed as a shock to the supply of mortgage credit in County A.

County B also experienced a shock to its supply of mortgage credit. Although County B did not rely as heavily on private financing, GSE financing experienced significant underwriting and pricing overlays from the private sector immediately after the financial crisis. The GSEs also imposed loan-level pricing adjustments and increased their guarantee fees, and put back defaulted mortgages to originators, all of which increased the cost of credit. We view the shock in the supply of mortgage credit in County B to be smaller than that in County A.

County $\mathrm{C}$ also experienced a shock to its supply of mortgage credit, although County $\mathrm{C}$ did not rely heavily on private or GSE financing. The FHA and VA increased the cost of their mortgage insurance programs starting in 2008 (Chart 2), which increased the cost of credit. However, underwriting standards were essentially unchanged, and aggressive putbacks of FHA mortgages did not start until well after the financial crisis subsided. We view the shock in the supply of mortgage credit in County $\mathrm{C}$ to be smaller than that in Counties B and A.

Our results suggest that pre-crisis FHA/VA shares were an important buffer against large-scale credit shocks. Participation in FHA/VA programs during and immediately after the crisis may have also been instrumental in accommodating potential mortgage borrowers, particularly after household credit quality had fallen. In principle, Fannie Mae and Freddie Mac might have extended credit to households with marginal credit quality, but institutions in conservatorship with significant hits to their private capital are more likely to tighten, rather than loosen, credit standards. Given their ambiguous relationship with the government compared with the FHA (more government involvement) and the private sector (less government involvement), we expect the GSEs' response to mitigating an economic downturn to lie between those of the FHA and the private sector (see Passmore and Sherlund 2016 for more details). 
CHART 2

FHA Annual Mortgage Insurance Premiums

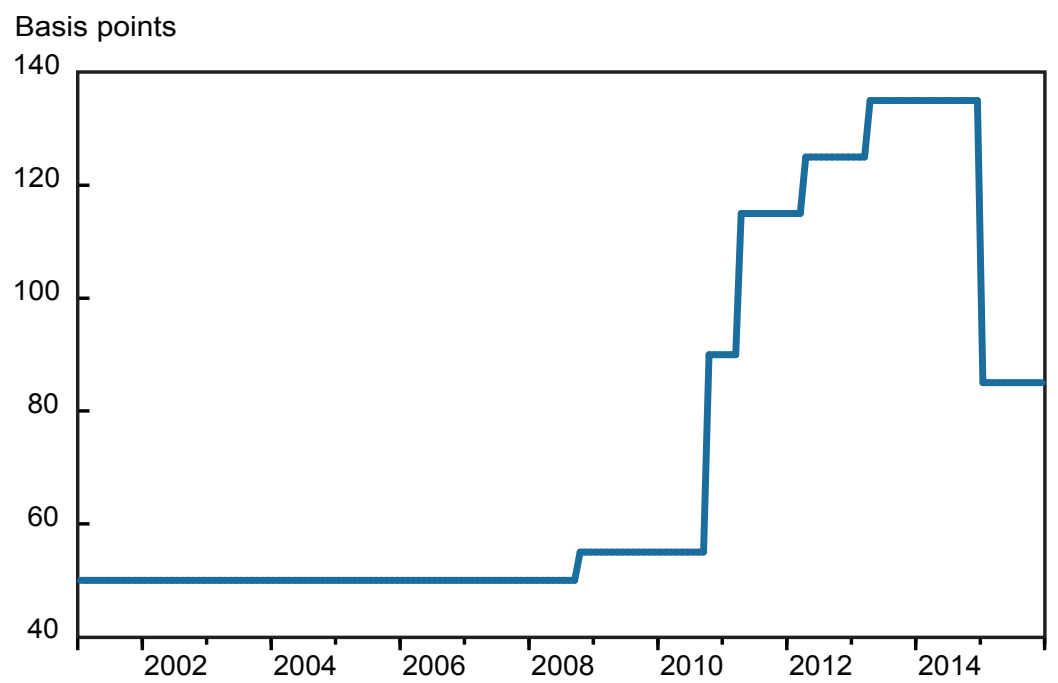

Source: Department of Housing and Urban Development.

Note: Chart shows the FHA annual mortgage insurance premium during the period 2001-15.

To understand the effects of government mortgage programs on the real economy, we estimate how the intensity of use of FHA/VA and GSE programs in counties influenced unemployment rates, new automobile purchases, home prices, home sales, mortgage purchase originations, and mortgage delinquency rates. However, unlike in an ideal experimental setting in which treatment and control groups are clearly and randomly assigned, the use of FHA/VA and GSE programs vary in intensity from county to county and depend on county characteristics. We thus follow the approach of Hirano and Imbens (2004) to estimate the effect of treatment doses of pre-crisis FHA/VA or GSE shares on economic outcomes. This procedure also accounts for the propensity of a county to select its FHA/VA and GSE market shares conditional on economic fundamentals such as average income, home price appreciation, and the unemployment rate. ${ }^{3}$

Our methodology establishes that government programs are instrumental in economic outcomes beyond the house price boom and bust. Once we condition on our set of pre-crisis, county-level observable variables, the estimated propensity scores balance pre-crisis trends across counties. In other words, when weighted by the estimated propensity scores, mean pre-crisis house price appreciation and mean pre-crisis unemployment rates are similar for high and low FHA/VA-share counties, as well as for high and low GSE-share counties. However, starting with the financial crisis, large differences in mean house price appreciation and mean unemployment rates emerge between low FHA/VA-share counties and high FHA/VA-share counties, and between low GSE-share counties and high GSE-share counties. 
TABLE 1

Outcomes Relative to 2005 by Pre-Crisis FHANA Share and GSE Share

\begin{tabular}{|c|c|c|c|c|c|c|c|c|}
\hline \multirow[b]{3}{*}{ Share } & \multicolumn{4}{|c|}{ FHA/VA } & \multicolumn{4}{|c|}{ GSE } \\
\hline & \multicolumn{2}{|c|}{2009} & \multicolumn{2}{|c|}{2014} & \multicolumn{2}{|c|}{2009} & \multicolumn{2}{|c|}{2014} \\
\hline & Low & High & Low & High & Low & High & Low & High \\
\hline Unemployment rate & 2.02 & 1.69 & 1.34 & 1.21 & 1.93 & 1.72 & 1.33 & 1.17 \\
\hline New automobile sales & .60 & .68 & .81 & .99 & .60 & .75 & .89 & .97 \\
\hline Home prices & .78 & .96 & .88 & 1.03 & .78 & .96 & .88 & 1.01 \\
\hline Home sales & .50 & .65 & .51 & .61 & .54 & .65 & .52 & .65 \\
\hline $\begin{array}{l}\text { Mortgage purchase } \\
\text { originations }\end{array}$ & .47 & .59 & .56 & .68 & .47 & .62 & .52 & .74 \\
\hline $\begin{array}{l}\text { Mortgage } \\
\text { delinquency rates }\end{array}$ & 15.97 & 2.96 & 6.08 & 2.14 & 12.16 & 3.73 & 4.69 & 2.09 \\
\hline
\end{tabular}

Source: Authors' estimates.

Notes: Table shows how unemployment rates, new automobile sales, home prices, home sales, purchase mortgage originations, and mortgage delinquency rates in 2009 and 2014 varied by FHA/VA and GSE market shares during the period from 2004 through the first half of 2007 . Outcomes are measured relative to their pre-crisis levels.

\section{Results}

Table 1 shows how county-level unemployment rates vary relative to their 2005 levels by pre-crisis FHA/VA and GSE shares (see Passmore and Sherlund 2016 for more details). Even though unemployment rates increased substantially for all county types, we see smaller increases relative to 2005 for counties with higher pre-crisis FHA/VA shares for both the crisis and post-crisis periods. Similarly, the increases were smaller, though to a lesser extent relative to counties with higher pre-crisis FHA/VA shares, for counties with higher pre-crisis GSE shares. By the end of 2009, unemployment rates had more than doubled in counties that had low pre-crisis FHA/VA shares in 2005 compared with only a 69 percent increase in counties with high pre-crisis FHA/VA shares. Unemployment rates had increased 93 percent in counties that had low pre-crisis GSE shares in 2005 compared with a 72 percent increase in counties with high pre-crisis GSE shares. Similarly, by the end of 2014, unemployment rates were 34 percent higher in counties with low pre-crisis FHA/VA shares in 2005, but were 21 percent higher in counties with high pre-crisis FHA/VA shares. Unemployment rates had increased 33 percent in counties with low pre-crisis GSE shares in 2005 compared with 17 percent in counties with high pre-crisis GSE shares.

Table 1 shows that the results were similar for new automobile purchases, home prices, home sales, mortgage purchase originations, and mortgage delinquency rates. New automobile purchases, home prices, home sales, and mortgage purchase originations decreased across the 
TABLE 2

Effect of 10-Percentage-Point Increase in Program Use

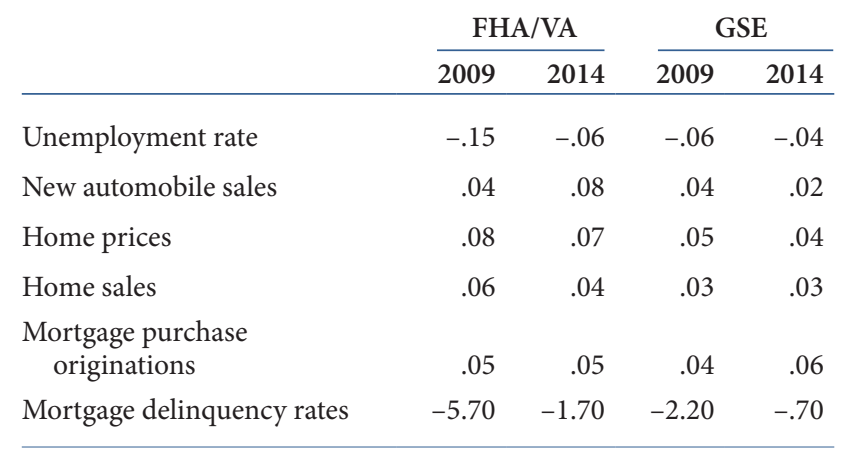

Source: Authors' estimates.

Notes: Table shows the effect of a hypothetical 10-percentage-point increase in FHA/VA or GSE market shares during the period from 2004 through the first half of 2007 , on unemployment rates, new automobile sales, home prices, home sales, purchase mortgage originations, and mortgage delinquency rates in 2009 and 2014. Outcomes are measured as the average slope of the estimated dose-response functions summarized in Table 1 over 10-percentage-point market-share increments.

board from 2005 to 2009. But looking across pre-crisis FHA/VA and GSE shares, these declines were smaller for higher pre-crisis FHA/VA and GSE share counties both in 2009 and 2014. Similarly, mortgage delinquency rates increased across county types from 2005 to 2009, but less in counties with higher pre-crisis FHA/VA and GSE shares.

We now explore whether the FHA mortgage program might have been more effective at mitigating the effects of economic distress than the GSE programs given that FHA underwriting and pricing were more constant over this period. As described above, the GSEs' underwriting tightened and credit pricing increased more than the FHA's. Furthermore, GSE lending experienced more substantial underwriting and credit pricing overlays from the private sector.

To compare the effectiveness of the two government mortgage programs, we calculate the average response of increasing the pre-crisis FHA/VA or GSE share by 10 percentage points (Table 2). Expanding the use of the FHA/VA mortgage program by 10 percentage points in a county before the financial crisis would be expected to have lowered the unemployment rate about 15 percent in 2009 and 6 percent in 2014. The same 10-percentage-point expansion in the pre-crisis GSE share would be expected to have lowered the unemployment rate about 6 percent in 2009 and 4 percent in 2014.

We find similar results for new automobile purchases and a set of housing indicators. Increasing the pre-crisis FHA/VA share by 10 percentage points would have increased new automobile purchases by 4 percent in 2009 and 8 percent in 2014. A 10-percentage-point increase in the pre-crisis GSE share would have increased new automobile purchases by 4 percent in 2009 and 2 percent in 2014. Increasing the pre-crisis FHA/VA share by 10 percentage points would have increased home prices by 8 percent in 2009 and 7 percent in 2014, home sales by 6 percent in 
2009 and 4 percent in 2014, and mortgage purchase originations by 5 percent in both 2009 and 2014. A 10-percentage-point increase in the pre-crisis GSE share would have increased home prices by 5 percent in 2009 and 4 percent in 2014, home sales by 3 percent in both 2009 and 2014, and mortgage purchase originations by 4 percent in 2009 and 6 percent in 2014 . We also find that increasing the pre-crisis FHA/VA share would have lowered mortgage delinquency rates in 2009 and 2014 more than a similar 10-percentage-point increase in the pre-crisis GSE share.

These large variations in economic effects across counties arise because of differences in participation in government mortgage channels, even though these channels would likely have only small differences in mortgage rates or credit costs. As a result, the variation in economic outcomes across counties during the financial crisis should reflect variations in the credit each government mortgage channel provides lenders or borrowers, or both, during the financial crisis. The persistence of better outcomes with higher pre-crisis use of FHA/VA lending is consistent with a view that less procyclical government underwriting standards and credit risk pricing — backed by a securitization outlet with the full faith and credit of the government-can stimulate additional economic activity during and after a financial crisis.

\section{IMPLICATIONS FOR GSE REFORM}

GSE reform plans vary in terms of proposed government ties. Our research suggests the link between the catastrophic risk insurer and the government should be carefully considered. In addition, the ways credit qualifications for GSE securitization would change during and after financial crises, and whether the GSEs would operate in a countercyclical manner, should be taken into account. Our empirical results suggest that an entity tightly linked to the government during catastrophic events would likely accelerate an economic recovery from a severe recession. That entity would need government backing to "lean against the wind" after an economic downturn, in contrast with the withdrawal of private capital often associated with financial crises.

Almost all GSE reform plans propose a government-backed, catastrophic risk insurer. Some of these plans propose insurers that would be true government entities with a full-faith-and-credit guarantee, like Ginnie Mae. Other plans would create entities with more distance from the government. Our results suggest that access to a full-faith-and-credit government guarantee would enable the catastrophic risk insurer to avoid imposing tighter underwriting standards or higher prices during a recession.

This finding also suggests substantial government involvement because private sector credit often contracts significantly during crises. To successfully promote economic recovery, an institution like the FHA, which promotes credit extension without increasing the credit risk premiums as much as the private sector or the GSEs, might be needed.

Many GSE reform proposals inject more private capital than the current GSEs. Such reforms might involve more procyclical costs and standards than GSE conservatorships. For example, many proposals rely on credit risk transfers (CRTs) to the private sector to cover noncatastrophic risk. ${ }^{4}$ Such transfers may be highly desirable during normal economic times because the private sector is well suited to manage normal, or even somewhat elevated, levels 
of mortgage default. But our results suggest that credit costs might rise or underwriting standards tighten quickly without a more explicit link between the government and the GSEs.

Moreover, if substantial systemic risk is transferred to the private sector, the negative consequences of a widespread crisis may not be avoided. Uncovered social costs prompt government intervention in the mortgage market. However, large losses imposed on private investors at the same time may formally transfer risk from the government, but then require government action to mitigate the social costs of the defaults (see Passmore and von Hafften 2018).

For many GSE reform proposals, a key missing component is an FDIC-like institution-a specialized government insurer to mitigate runs and absorb losses in the place of debt holders. First proposed in Hancock and Passmore (2011), an FDIC-like institution would limit the losses imposed on CRT and MBS investors during the most severe economic downturns. Funded by the equivalent of a deposit insurance premium and backed by a substantial line of credit from the U.S. Treasury, the FDIC-like institution would compensate securities holders for their losses. In the most severe economic downturns, such an institution would quell investors' fears about shuffling losses from GSEs to private sector investors, encourage continued extension of credit under unfavorable conditions, and allow the government to encourage mortgage originators to lean "against the wind" without unduly raising mortgage costs.

\section{Conclusion}

We find a strong correlation between counties that participated more heavily in FHA/VA and GSE mortgage lending before the crisis and better economic outcomes during and after the crisis. Indeed, we find that these better economic outcomes can be attributed directly to greater pre-crisis participation in FHA/VA and GSE mortgage programs. While the financial crisis was a substantial shock that hit all counties, the adverse effects were smallest in counties with higher pre-crisis FHA/VA or GSE shares. Counties more reliant on FHA/VA or GSE lending experienced smaller increases in unemployment rates, smaller declines in new automobile purchases, home prices, home sales, and mortgage purchase originations, and smaller increases in mortgage delinquency rates. Some of these effects were still evident in 2014, years after the crisis.

Overall, we find that the FHA was a more effective countercyclical tool during and after the 2007-09 financial crisis than the GSEs. The FHA's success may be linked to its greater willingness to extend credit to marginal borrowers and its explicitly backed government securitization outlet. This finding may have implications for GSE reform: Greater access to government backing during crises may mitigate tighter underwriting standards and rising securitization costs. 


\title{
Notes
}

Acknowledgments: The authors thank Alex von Haffen for his excellent assistance in preparing this article.

\begin{abstract}
${ }^{1}$ Passmore and Sherlund (2017) investigate the role of government mortgage programs more generally and find that counties with higher pre-crisis government shares had better economic outcomes during and after the Great Recession than counties with lower pre-crisis government shares.

${ }^{2}$ Bhutta and Ringo (2017) explore the effects of the 2015 annual mortgage insurance premium cut on home purchase originations and home prices.

${ }^{3}$ In particular, our first-stage selection regressions include pre-crisis, county-level measures of credit quality, income, population and demographics, economic fundamentals, housing affordability, and market competition. The credit-quality measures consist of median risk scores, the proportion of the population with a credit report, and the proportions of credit reports within certain risk-score ranges. Our income measures include average wages and salaries, average exemptions, average dividends and interest, and the proportions of tax returns within certain income ranges. The population and demographic measures consist of total population, poverty rates, proportion female, and proportions of the population within certain age ranges, within race or ethnicity definitions, and with certain education levels. Our economic fundamentals include the unemployment rate at the end of 2005 and house price appreciation during 2005, from 2001 to 2004, 1996 to 2000, 1986 to 1995, and 1976 to 1985. Our housing affordability measure is the median home price over average income. Finally, the mortgage market competition measures include the total number of lenders reporting to HMDA in 2005, the change from 1998, the difference between the median home price and the conforming loan limit, and the proportion of home sales with prices at or below 125 percent of the conforming loan limit.
\end{abstract}

${ }^{4}$ Finkelstein, Strzodka, and Vickery (2018). 


\section{REFERENCES}

Bhutta, N., and D. Ringo. 2017. "The Effect of Interest Rates on Home Buying: Evidence from a

Discontinuity in Mortgage Insurance Premiums." Federal Reserve Board FinanCE and Economics

Discussion SERIES, no. 2017-086. https://doi.org/10.17016/FEDS.2017.086.

Federal Housing Finance Agency. 2017. "History of Fannie Mae \& Freddie Mac Conservatorships.”

https://www.fhfa.gov/Conservatorship/Pages/History-of-Fannie-Mae--Freddie-Conservatorships.aspx

Finkelstein, D., A. Strzodka, and J. Vickery. 2018. “Credit Risk Transfer and De Facto GSE Reform.”

Federal Reserve Bank of New York StAfF RePorTs. no. 838, February.

Hancock, D., and W. Passmore. 2011. "Catastrophic Mortgage Insurance and the Reform of Fannie Mae and Freddie Mac.” In M. Baily, ed., The Future of Housing Finance: Restructuring the U.S. Residential Mortgage Market, 111-45. Washington, D.C.: Brookings Institution Press.

Hirano, K., and G.W. Imbens. 2004. "The Propensity Score with Continuous Treatments."

In A. Gelman and X. Meng, eds., Applied Bayesian Modeling and Causal Inference from Incomplete Data Perspectives, 73-84. West Sussex: John Wiley and Sons.

Passmore, W., and S. M. Sherlund. 2016. "FHA, Fannie Mae, Freddie Mac, and the Great Recession."

Federal Reserve Board Finance and Economics Discussion Series, no. 2016-031.

https://doi.org/10.17016/FEDS.2016.031r1.

— 2017. "FHA, Fannie Mae, Freddie Mac, and the Great Recession.” Unpublished paper.

Passmore, W., and A. H. von Hafften. 2018. "GSE Guarantees, Financial Stability, and Home Equity

Accumulation." Federal Reserve Bank of New York Economic Policy Review 24, no. 3

(December): 11-27.

The Economic Policy Review is published by the Research and Statistics Group of the Federal Reserve Bank of New York. The views expressed are those of the individual authors and do not necessarily reflect the position of the Federal Reserve Bank of New York or the Federal Reserve System. Economic Policy Review articles may be reproduced for educational or training purposes, provided they are reprinted in full; include credit to the author(s), the publication, and the Bank; and include the publication's disclaimer.

(C) 2018 The Federal Reserve Bank of New York 